\title{
Applications Of Lipase Enzyme In Fatty Monoethanolamide Synthesis Based On Palm Fatty Acid Distillate
}

\author{
Fachraniah Ahmad ${ }^{1}$, Eka Kurniasih ${ }^{1}$, Faridah $^{1}$ and Ariefin ${ }^{2}$ \\ \{fachraniah@pnl.ac.id, ekakurniasih@pnl.ac.id, ariefin@pnl.ac.id\} \\ ${ }^{1}$ Department of Chemical Engineering, Politeknik Negeri Lhokseumawe, Lhokseumawe, Indonesia \\ ${ }^{2}$ Department of Mechanical Engineering, Politeknik Negeri Lhokseumawe, Lhokseumawe, Indonesia
}

\begin{abstract}
Monoethanolamide is a compound of nonionic surfactant which can be obtained through a reaction between Palm Fatty Acid Distillate (PFAD) with alkanolamine. It has $\mathrm{OH}^{-}$group, so it dissolves easily in water and is widely used in the cosmetics industry. The screening of enzyme was conducted in temperature of $60^{\circ} \mathrm{C}$ and the ratio of biocatalyst $0.2 \%(\mathrm{w} / \mathrm{w})$ in three types of lipase enzymes, which are Rhizomucor meihei, Candida antartica and Lipase sp. The determination of mole ratio level for PFAD/ethanolamine was conducted in four hour reaction times. The level of mole ratio of PFAD/ethanolamine was varied from $1: 1$ up to 1:10. Crude fatty monoethanolamide which is soluted in alcohol was separated from biocatalyst by using filtration method and carried on with distillation process to separate the ethanol from the product. Pure fatty monoethanolamide was gained as bottom product. Monoethanolamide was then confirmed in infra red spectrum (FT-IR). From the results of enzymes screening, it is known that Rhizomucor meihei is a type of enzyme that is able to hold the amidation reaction to provide the highest product conversion of $29.51 \%$ compared to other types of enzymes. While the increase in the ratio of moles PFAD/monoethanolamine gives the best results on the $1: 4$, and the conversion obtained is $86.25 \%$.
\end{abstract}

Keywords: amidation, enzymes, PFAD, monoethanolamine, Rhizomucor meihei

\section{INTRODUCTION}

Alkanolamide is obtained from the reaction between fatty acid with alkanolamine. The fatty acid used is that with $\mathrm{C}_{12}-\mathrm{C}_{18}$ carbon chain so it can allow palm fatty acid distillate (PFAD) as the raw material. Usually, alkanolamide is produced chemically by using oil or fat with alkanolamine in certain temperature and this way is assumed as the conventional way. But, it has some debilities regarding the energy use and the forming of the unwilling side product. The synthesis of alkanolamide with conventional way is held by using alkali catalyst in the temperature of $120^{\circ}-150{ }^{\circ} \mathrm{C}$. Finally, the product will contain amine soap which raises $\mathrm{pH}$, so it is necessary to have purification process afterward. For this reason, an enzymatic process is developed to obtain monoethanolamide from PFAD by using biocatalyst. The 
biocatalyst could be from lipase enzyme but it should have the specific characteristic in the substratum which contains palmitic acid. The specific characteristic is the ability of an enzyme to activate in one type of certain substrate [1].

Rhizomucor meihei, Candida antartica and Lipase sp. are types of lipase enzymes which usually used in the reaction of fatty acid esterification to produce fatty acid methyl ester (FAME), cosmetic (palm oil emulsifier) that contain high palmitic acid, food industry (cocoa butter), vegetable oil industries such as corn oil, sunflower oil, and olive oil [2]. The using of enzymatic reaction in fatty acid and vegetable oil has several advantages, they are: (i) the characteristics of high lipase which will gain pure product, (ii) relatively use low pressure and temperature, (iii) relatively lower cost of waste management and (iv) the product resulted is more eco-friendly than product resulted from chemical process conventionally [3].

Monoethanolamide is a compound that classified as fatty amide and nonionic surfactant that used widely as the material in producing shampoo, shower foam, latex stabilize, corrosion resistor, cleaning house products and liquid detergent [4]. A surfactant is a compound that has two groups which are hydrophobic (lipophilic) and hydrophilic (lipophobic) in one molecule, so it is called as amphilic compound [5]. Indonesia import of surfactant raise around 44.500 tons and it is predicted to raise more year to year in line with the growth of cosmetic, food, pharmacy, textile and tannery industries [6].

Indonesia is one of the biggest producers of palm oil in the world. Some of the products are exported in raw palm oil and the rest is used as the raw material for domestic industries. The consumption of palm oil in the country is only as cooking oil, margarine, soap and oleochemical industries that produce palm fatty acid, methyl ester, and a fatty alcohol. In cooking oil industry, there is a refining phase which intends to improve the quality of the oil. In this phase, besides the main product, cooking oil, it is also produced the side product which is palm fatty acid distillate (PFAD) that contains high palmitic acid, about $56.55 \%$. This indicates the availability of the raw material for surfactant industries which involved enzymatic reaction.

Enzym functions as a catalyst in the biochemical process occurring in a cell inside or outside a cell. An enzyme can accelerate the reaction $10^{8}$ up to $10^{11}$ faster than the reaction without a catalyst. Thus, an enzyme can be an efficient catalyst, besides it has a high specification. Like other catalysts, an enzyme can lower the activating energy of a chemical reaction. Some chemical reactions need energy (endergonic reaction) and some produce or release energy (exergonic). This specific characteristic of enzyme makes it only able to work in one reaction only [1].

To be able working with a compound or substratum, it must relate or connect with the substratum. An enzyme has bigger size that substratum, therefore not all part of an enzyme can connect directly with the substratum. The relation between substratum and enzyme only occur in a certain part. The part of the enzyme which relates or connect with the substratum called active site. The relation might only happen if the active site has space to accommodate the substratum. If the substratum has other size or confirmation, it cannot be accommodated in the active site of the enzyme. In this case, the enzyme has no function to the substratum. This is the reason why every enzyme has the specific characteristic to the certain substratum. The relation or connection between the enzyme and the substratum cause the complexity of substratum enzyme. This complexity is an active one which is temporary and will be decomposed if the expecting reaction has occurred. Simply saying, the decomposition of a compound or substratum by the enzyme can be described as a following reaction:

$$
E+S \leftrightarrow E S \leftrightarrow E+P
$$


E, S, ES and P, each of them symbolize the enzyme, substratum, enzyme substratum complexity and the product (for enzyme composition which is the multiple of identical subunits, E describes the site activity of enzyme molecule and non-enzyme molecule). Based on this model, if the concentration of the substratum becomes high until it is enough to change enzyme completely to ES form, so the second step of the reaction has the limit of speed and the whole of reaction level become not sensitive [7]

\section{METHODS}

\subsection{Material}

PFAD, monoethanolamine, n-Hexane, Rhizomucor meihei (Novozyme), Candida antartica (Lipozyme) and Lipase sp.

\subsubsection{Biocatalyst Screening}

Enzyme Screening is intended to choose the type of biocatalyst which has the highest conversion to amidation reaction through yield obtained. It is done in $60^{\circ} \mathrm{C}$, the mol ratio of PFAD/ monoethanolamine is (1:4) and biocatalyst ratio is $0.2 \%(\mathrm{w} / \mathrm{w})$ in 3 (three) types of lipase enzymes, which are Rhizomucor meihei, Candida antartica, and Lipase sp. Yield product of fatty monoethanolamide formed is described through the percentage of conversions decrease of free fatty acid (FFA).

\subsubsection{Synthesis of Monoethanolamide}

Type of enzyme which gives the highest yield in the screening phase is chosen as the enzyme in synthesizing the next fatty monoethanolamide. In this phase, the reaction of enzymatic amidation is occurred based on PFAD as the limit reactant and excessive monoethanolamine. The usage of monoethanolamine is more intended to raise the power of formed peptide bond.

The reaction of the monoethanolamide formation discribes in equation (2) while the synthesis of monoethanolamide is shown in Figure 1.

$$
\begin{aligned}
& \mathrm{COOH}+\mathrm{H}-\mathrm{NH}-\mathrm{CH}_{2} \mathrm{CH}_{2} \mathrm{OH} \rightarrow \mathrm{RCONHCH}_{2} \mathrm{CH}_{2} \mathrm{OH}+\mathrm{H}_{2} \mathrm{O} \\
& \text { PFAD Ethanolamine Monoethanolamida water }
\end{aligned}
$$




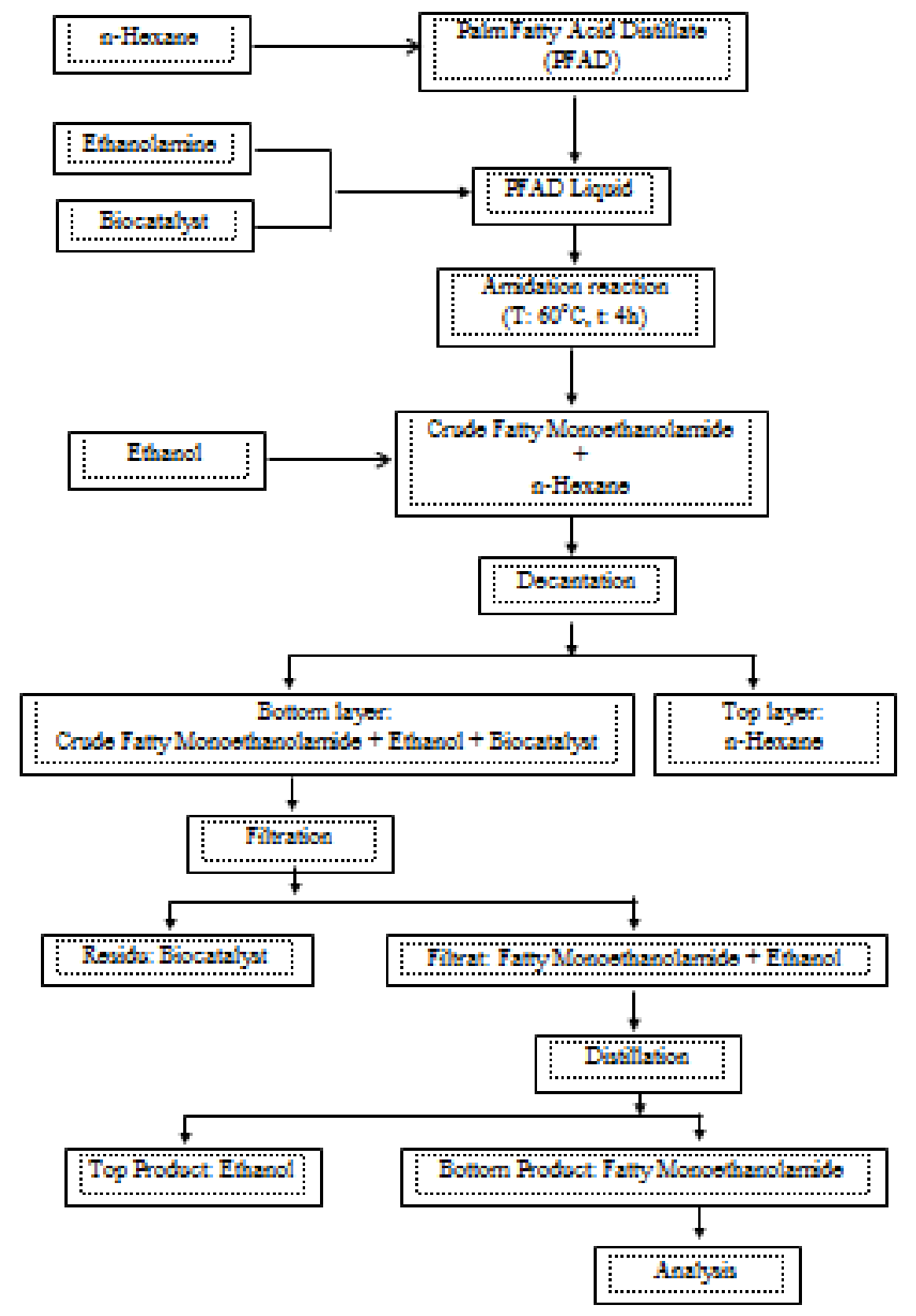

Fig. 1 Fatty Monoethanolamide Synthesis 


\section{DISCUSSION}

\subsection{Biocatalyst Screening}

From the result of biocatalyst screening that has been done to the three types of biocatalyst; Rhizomucor meihei (Novozyme), Candida antartica (Lipozyme), and Lipase sp. It is known that Rhizomucor meihei gives the highest conversion compared to other types of enzymes. The conversion is calculated from the change of free fatty acids content of the raw material and the product. High percentage of FFA reduction indicates that many palm fatty acids which are formerly free ( no bond with the second substratum) become bonded with the second substratum, in this case, ethanolamide forms product enzyme complex.

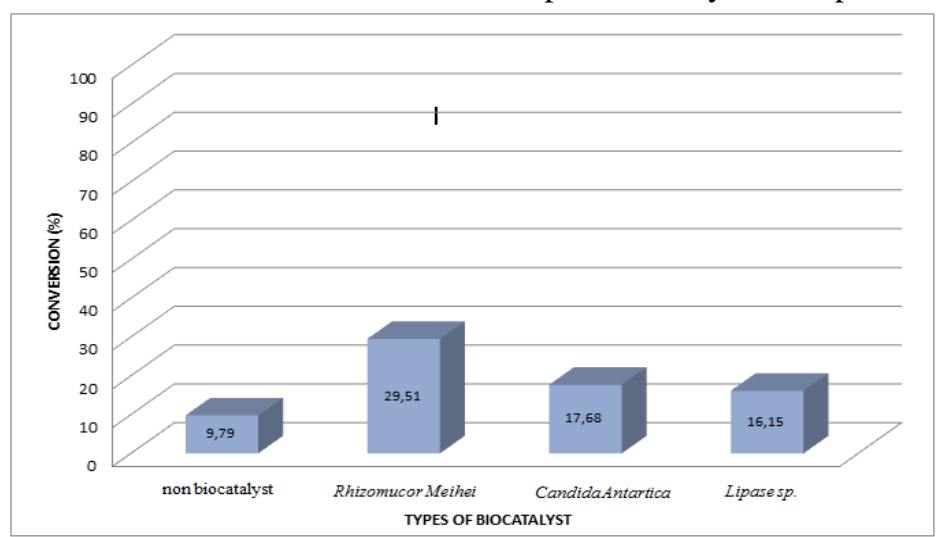

Fig. 2 The effect of Biocatalyst type to the conversion of Monoethanolamide

It is known that Rhizomucor meihei has high specificity to the amidation reaction based of PFAD with $29.51 \%$ conversion. Rhizomucor meihei is able to work in PFAD substratum with medium up to long chain fatty acids $\left(\mathrm{C}_{14}-\mathrm{C}_{18}\right)$ as the biggest component. This is in accordance with the previous research done by [8] and [3] about the usage of Rhizomucor meihei in the substratum with medium up to long chain fatty acids, which gives positive effect to biocatalyst variables. Based on the survey during this research, it can be concluded that Candida antartica is only able to work in the substratum with medium chain fatty acids content, thus the conversion gained is not real, while Lipase sp is known unable to hold the amidation reaction along the reaction time because its characteristic is more sensitive to the temperature change and the condition of the reaction. As the control to the reaction, the amidation reaction is done without enzyme to observe the specificity owned by each of the biocatalysts. For the amidation reaction control, the reduction of FFA is about $9.79 \%$ which shows the significant effect of the enzyme variables to the continuity of enzymatic reaction of amidation. For further research, Rhizomucor meihei is used as a permanent variable for the type of biocatalyst. The spectrum FT-IR of monoethanolamide is shown in Figure 3. 


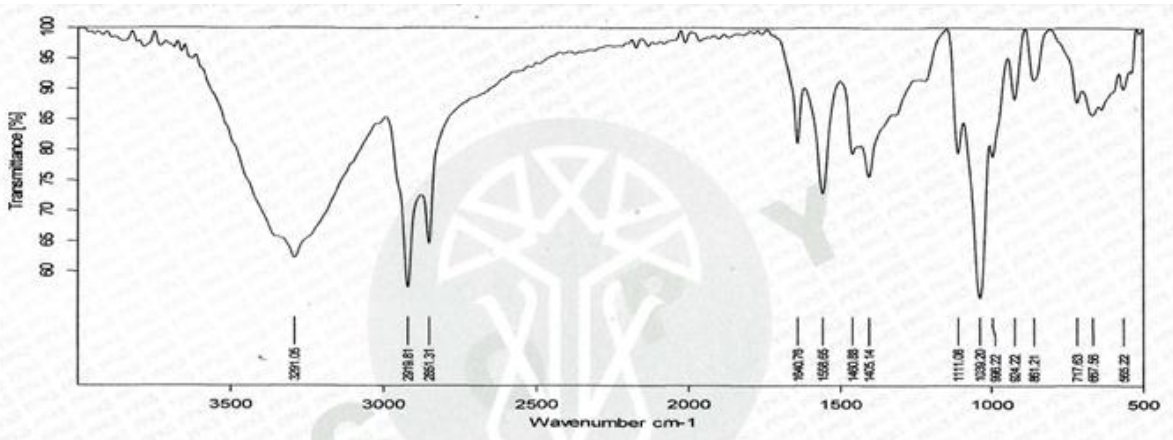

Fig. 3 Spectrum FT-IR of Monoethanolamide

Table 1. Non enzyme Fatty Monoethanolamide wavenumber.

\begin{tabular}{ll}
\hline Wavenumber $\left(\mathrm{cm}^{-1}\right)$ & Functional group \\
\hline 3374.09 & $-\mathrm{O}-\mathrm{H}$ \\
2916.47 & $-\mathrm{C}-\mathrm{H}$ \\
1774.24 & $-\mathrm{C}-\mathrm{O}$ (amine ester) \\
1645.95 & $-\mathrm{C}=\mathrm{O}$ (amide) \\
1466.60 & $-\mathrm{C}-\mathrm{N}$ \\
715.77 & $-\mathrm{C}-\mathrm{H}_{2}$ \\
\hline
\end{tabular}

Table 2. Fatty Monoetanolamide (Rhizomucor meihei) wavenumber

\begin{tabular}{cl}
\hline Wavenumber $\left(\mathrm{cm}^{-1}\right)$ & Functional group \\
\hline 3364.77 & $-\mathrm{O}-\mathrm{H}$ \\
2916.95 & $-\mathrm{C}-\mathrm{H}$ \\
1644.18 & $-\mathrm{C}=\mathrm{O}$ (amide) \\
1455.60 & $-\mathrm{C}-\mathrm{N}$ \\
715.85 & $-\mathrm{C}-\mathrm{H}_{2}$ \\
\hline
\end{tabular}

\subsection{Fatty Monoethanolamide Synthesis}

Monoethanolamide is a type of nonionic surfactant which functions as foaming boaster in cosmetic. Fatty monoethanolamide is produced by using ethanolamine and fatty acids. This research used PFAD as the source of fatty acids and excessive ethanolamine as the reactant. Excessive ethanolamine is used as observed reactant carrier.

The usage of excessive ethanolamine will chance to increase the power of formed peptide [9], however, the usage of the excessive ethanolamine may form more $\mathrm{H}_{2} \mathrm{O}$ molecules, so it is necessary to determine the precise mole ratio in this amidation reaction.

In this research, the level mol ratio of PFAD: Ethanolamine was examined from 1:1 until 1:10 to determine the optimum of mole ratio. The selection of mole ration PFAD : Ethanolamine is done in the condition of reaction in $60^{\circ} \mathrm{C}$, with biocatalyst ratio $0.2 \%(\mathrm{w} / \mathrm{w})$. This condition is shown in Figure 4.

Based on the result, it is known that the level mol ratio of PFAD:Ethanolamine (1:4) gives the optimum conversion, it is proven by doing the raising of ethanolamine and the conversion gained decrease significantly. This is caused by the barrying of substratum in the reaction 
system, because the substrate has completely bonded with the biocatalyst and together form the substratum enzyme complex and this fact is appropriate with the research done by Rahman (2003), that the raising of ethanolamine ration up to 1:10 give the reality of the decrease of product conversion.

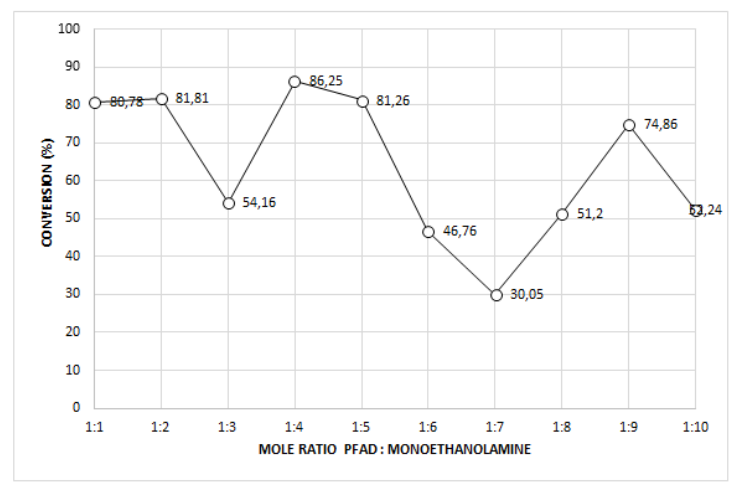

Fig. 4 The Effect of Mole ratio PFAD:Ethanolamine to the conversion of Monoethanolamide

\section{CONCLUSIONS}

From this research, it is known that Rhizomucor meihei gives the positive effect to the result of fatty monoethanolamide product conversion. Rhizomucor meihei is selective to the medium up to long chain fatty acid and able to hold the enzymatic amidation reaction. Mol ration of PFAD/ethanolamine (1:4) gives the best conversion, while the raising of ethanolamine ratio shows the substrate barrying in the substrate enzyme complex reaction because PFAD has reacted with monoethanolamine completely

\section{References}

[1] A. Poedjiadi and F. M. T. Supriyanti, "Dasar-dasar biokimia," Jakarta Univ. Indones., 1994.

[2] F. Hasan, A. A. Shah, and A. Hameed, "Industrial applications of microbial lipases," Enzyme Microb. Technol., vol. 39, no. 2, pp. 235-251, 2006.

[3] J. Elisabeth and A. Jatmika, "Preparasi Mono-dan Digliserida Dari Minyak Sawit Dengan Gliserolisis Enzimatik," J. Penelit. Kelapa Sawit, vol. 6, no. 1, pp. 79-94, 1998.

[4] A. B. S. M. B. Rahman, M.B. AbdulC.L. Yap, K. Dzulkeefly, R.N.Z. Abdul Rahman, "Synthesis of Palm Kernel Oil Alkanolamide Using Lipase," J. Oleo Sci., vol. 52, no. 2, pp. 65-72, 2003.

[5] K. K. Gautam and V. K. Tyagi, "Microbial Surfactants: A Review," J. Oleo Sci., vol. 55, no. 4, pp. 155-166, 2006.

[6] P. Hildebrandt, R. Schomäcker, and J. Starnick, "Kinetic Investigation of the BaseCatalyzed Glycerolysis of Fatty Acid Methyl Esters $\square \square \square$ Kinetische Untersuchungen zur basisch katalysierten Glyzerinolyse von Fettsäuremethylestern,” 2004. 
[7] M.T. Simanjuntak J. Silalahi, “Gugus Prostetik .," pp. 1-38, 2003.

[8] E. Kurniasih, "Optimasi Reaksi Amidasi Enzimatis Dietanolamida," no. i, pp. 191197, 2013.

[9] M. Serdaroğlu, B. Öztürk, and A. Kara, "An Overview of Food Emulsions: Description, Classification and Recent Potential Applications," Turkish J. Agric. Food Sci. Technol., vol. 3, no. 6, p. 430, 2015. 